\title{
Therapeutic Potential of Croton Blanchetianus for the Treatment of Gastric Ulcers: A Brief Review
}

\author{
Thainá dos Santos Dantas ${ }^{1,2}$ (i) , Alisson Macário de Oliveira ${ }^{3}{ }^{(\mathbb{D})}$, \\ Magda Rhayanny Assunção Ferreira 2 (D), Luiz Alberto Lira Soares 1,2,* (D) \\ 1 Postgraduate Program in Therapeutic Innovation, Federal University of Pernambuco (UFPE), Recife, PE, Brazil; \\ thaina.dantas@ufpe.br (T.S.D); luiz.albertosoares@ufpe.br (L.A.L.S.); \\ 2 Laboratory of Pharmacognosy (NUDATEF), Federal University of Pernambuco (UFPE), Recife, PE, Brazil.; \\ magda.ferreira00@gmail.com (M.R.A.F.); thaina.dantas@ufpe.br (T.S.D.); luiz.albertosoares@ufpe.br (L.A.L.S.); \\ 3 Department of Biochemistry, Federal University of Pernambuco (UFPE), Recife, PE, Brazil; \\ alissonmacario@hotmail.com (A.M.O.); \\ * Correspondence: luiz.albertosoares@ufpe.br (L.A.L.S.);
}

Scopus Author ID 12763838000

Received: 14.10.2021; Revised: 15.11.2021; Accepted: 19.11.2021; Published: 9.12.2021

\begin{abstract}
Natural products are considered one of the main sources that contribute to advances in research in medical science, in such a way that the elucidation of the mechanism of action enables the industry to design new drugs, providing new applications, inputs, and alternatives for the treatment of various pathologies. Studies show the importance of secondary metabolites, presenting pharmacological, microbiological, and food functions. Given the above, this review aims to describe the importance of studies with natural products, emphasizing the gastroprotective activity of the Croton genus. The genus Croton (Euphorbiaceae) is characteristic of the Brazilian biome, especially in the semiarid climate. The species of the genus have anti-inflammatory and curative properties, correlating their gastroprotective effect. Among the plurality of species, one that has therapeutic and economic potential is Croton blanchetianus. The population widely uses the species as it has medicinal properties, used to prepare teas and compresses, helping with inflammatory processes and pain. Thus, it was observed that Croton species have great potential in anti-inflammatory activity and gastroprotection. Therefore, studies with the Croton blanchetianus species should be deepened regarding this activity, providing greater knowledge about this plant.
\end{abstract}

Keywords: natural products; gastric ulcer; Croton.

(C) 2021 by the authors. This article is an open-access article distributed under the terms and conditions of the Creative Commons Attribution (CC BY) license (https://creativecommons.org/licenses/by/4.0/).

\section{Introduction}

Brazil has one of the greatest biological diversities in the world, and currently, all this biodiversity has a high economic value for several purposes, since natural products are used in the food industry, as well as for the development of new therapeutic approaches [1]. Natural products are considered one of the main sources that contribute to the research advances in medical science, in such a way that the elucidation of the action mechanism of the active principle enables the industry to design new drugs, providing new applications, inputs, and alternatives for the treatment of various pathologies [2].

In recent times, great advances have been observed in studying chemical compounds present in plant species, an essential premise for producing new therapeutic products [3]. One of the main products of plant origin is the plant extracts, composed of a mixture of several 
molecules with the therapeutic value obtained from medicinal plants by means of specific processes [4].

Among the plurality of species, one that holds therapeutic and economic potential is Croton blanchetianus. It is a species of the Euphorbiaceae family, characteristic of the Brazilian biome, especially the semiarid climate. It is characterized as a shrub that can reach up to a small tree, adapted to arid conditions [5]. For the species, there are reports of the presence of several secondary metabolites, such as flavonoids, alkaloids, and terpenes, which are responsible for the biological activities already described for the species [6].

The literature provides several studies on the therapeutic activities of Croton blanchetianus, among which are the gastroprotective, anti-inflammatory, antinociceptive, and antimicrobial activities, among others [5-7]. Thus, this review describes the importance of studies with natural products regarding their pharmacological activities, emphasizing the gastroprotective activity of species of the genus Croton.

\section{Materials and Methods}

This study is a literature review carried out in several databases (SciELO, PubMed, and Science Direct) and included original articles, books, dissertations, and theses. The main aspects related to anti-inflammatory, antimicrobial, and gastroprotective activities and the chemical composition of the species, published between 2006 and 2021, were considered. The keywords used were: secondary metabolites, plant extract, Croton, gastroprotection, and gastroprotective mechanism.

\section{Results and Discussion}

\subsection{Secondary Metabolites.}

Plants have a variability of secondary metabolites synthesized by several metabolic pathways, which can protect the species and can be considered active principles, many of which are still unknown. Several studies show the importance of these compounds, from the performance of pharmacological or toxicological functions to their use in the food and cosmetics industries [8-11].

Such bioactive compounds can be extracted from different parts of plants, such as leaves, fruits, flowers, seeds, bark, and roots [12]. In this sense, products obtained from natural sources, such as plant species, have been the object of study. Considering the above and the importance of secondary metabolites, in this review, we will emphasize the three major groups of secondary metabolism, polyphenols, terpenes, and alkaloids, exploring the general view of the application of these molecules in gastric ulcers $[9,13]$.

\subsubsection{Polyphenols.}

The largest group of secondary metabolites is polyphenols, consisting of compounds with an aromatic ring and can be found in both simple and complex forms. Among the compound classes that are part of this group are flavonoids and tannins, which will be discussed here [14].

Flavonoids constitute one of the largest and most important groups of phenolic compounds distributed in most plant species. Structurally, they are composed of a chain of the C6-C3-C6 type, which comprises 3 rings (A-B-C) [15]. The group is subdivided into classes 
of flavanones, flavones, flavonol, flavonols, flavanol, and flavandiol, in addition to isoflavones and anthocyanidins (Figure 1), which are present in different concentrations in plant species and are recognized for having good antioxidant activity $[3,16,17]$. In addition to antioxidant activity, they have anti-inflammatory, antimicrobial, and antiviral properties, and some reviews report the benefits of flavonoids in reducing cardiovascular disease and obesity [16], eye diseases [11], anticancer [18], among others [1].

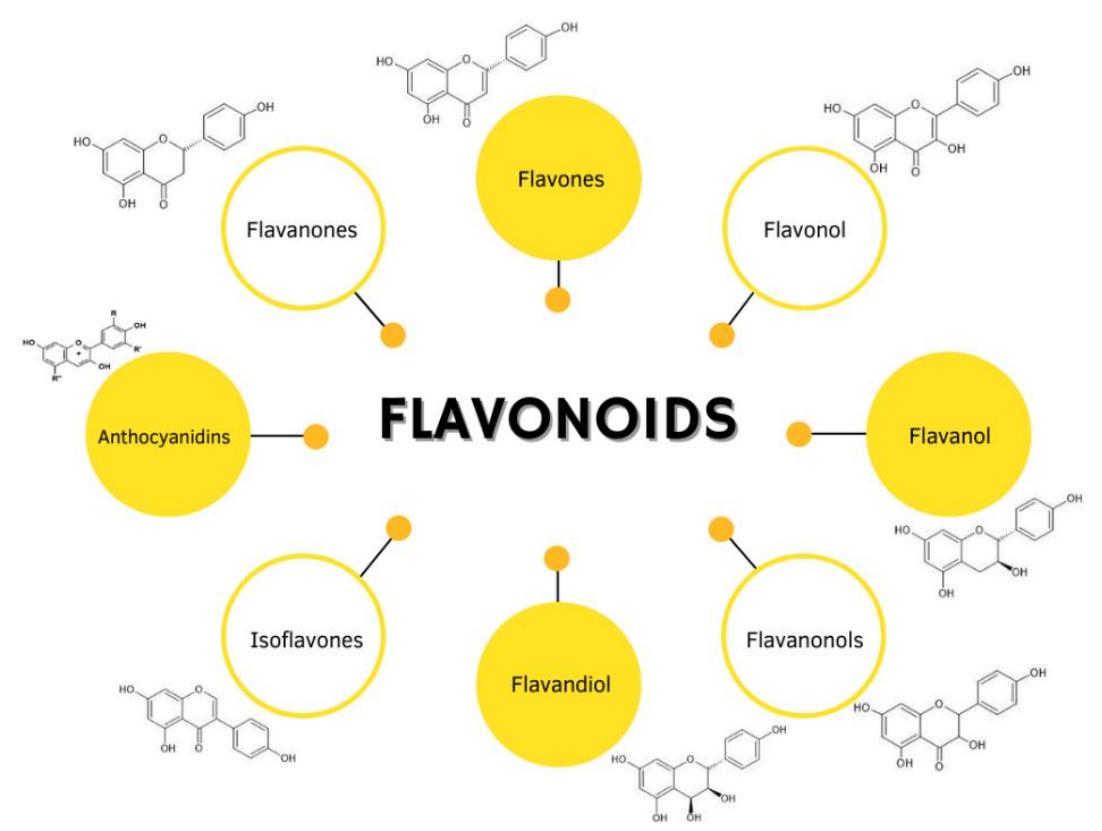

Figure 1. Flavonoids groups.

Tannins are also part of the polyphenols and are present everywhere in the plant. Most tannins have a high molecular weight (between 1,000 and 5,000) and are recognized for their ability to form strong complexes with carbohydrates and proteins. In addition, they protect the plant against microbial agents, herbivores, and insects [19-21]. Tannins are divided into two classes: hydrolyzable tannins, whose main representatives are gallic acid and ellagic acid, and condensed tannins, consisting of oligomers and polymers formed by several flavon-3-ol units, whose main representative is catechin [22, 23] (Figure 2).

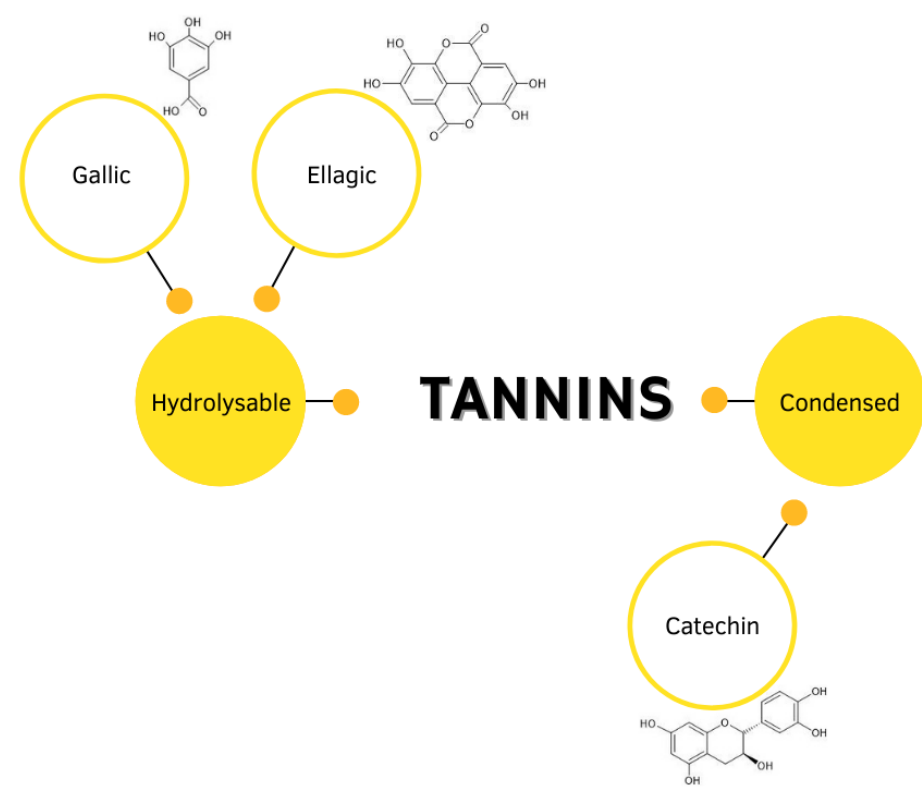

Figure 2. Tannins groups. 
For gastroprotection activities, these chemical compounds have an important role. The evaluation of the methanolic extract of Mouriri pusa leaves, rich in polyphenols, showed the important role of these compounds in the protection of gastric mucosa [24]. de Cássia dos Santos, Bonamin, Périco [25] studied the leaves of Byrsonima intermedia and obtained fractions rich in polyphenols, such as flavonoids and tannins, and obtained a good gastroprotective effect on ulcers induced by ethanol, indomethacin, and cysteamine. In another study performed with hydroalcoholic extract of Urera baccifera leaves [26], which presented flavonoids as the main metabolites, evidenced the role of the class as an anti-inflammatory and healing agent in ethanol-induced ulcers.

\subsubsection{Terpenes.}

Terpenes are natural compounds built from isoprene units, also known as terpenoids or isoprenoids, occurring in nature as hydrocarbons, alcohols, glycosides, and ethers, aldehydes, ketones, carboxylic acids, and esters. Some terpenes are part of the composition of volatile oils (or essential oils) and have fat-soluble characteristics. These compounds can be found in leaves, roots, stems, flowers, barks [27-29]. Some activities of terpenes present in plant species are well described in the literature, such as anticancer [30], antifungal [31], and antioxidant activity [32].

Research describes the use of essential oils in gastroprotective mechanisms, decreasing the areas of ulcer lesions. For example, a study involving essential oil obtained from the bark of Vanillosmopsis arborea [33] contained $\alpha$-bisabolol as the compound that acted most in the gastroprotective effect in ethanol-induced ulcers. In another study with terpenes, nerolidol was used to obtain an inclusion complex with $\beta$-cyclodextrin, performing gastroprotective action in ulcers induced by ethanol and indomethacin and anti-inflammatory activity in symptoms of rheumatoid arthritis, demonstrating the healing potential of this compound [34].

\subsubsection{Alkaloids.}

Alkaloids constitute another large group of substances that are part of secondary metabolism. The species containing alkaloids constitute a varied group, both with respect to taxonomy and chemical composition. The presence of basic nitrogen (whether in the heterocyclic ring or not) becomes a common factor [21, 35]. In addition to plants, they can be found in algae, fungi, and animals [36]. Alkaloids have several biological properties already reported, including anti-inflammatory and antioxidant activity[37], antitumor, antimycotic activity [38], and antifungal [39].

Studies conducted for the healing of gastric ulcers show the alkaloids as compounds that act with this property, as reported in Ugwah, Ugwah-Oguejiofor, Etuk [40], which used the aqueous extract of Balanites aegyptiaca bark to study the antiulcer activity. The phytochemical profile showed the presence of alkaloids, terpenes, saponins, and flavonoids, being the main responsible for the healing action of the injured area. In another study, the 2phenylquinoline compound derived from Galipea longiflora bark was extracted. Its use in gastric lesions decreased the area of ulcers and increased the levels of mucosal antioxidant factors, corroborating the gastroprotective activity [41].

Given the described works, it is possible to infer that the chemical compounds in plant species promote a healing and protective effect on gastric lesions. In Figure 3, some compounds that act in the gastroprotective activity are described. 


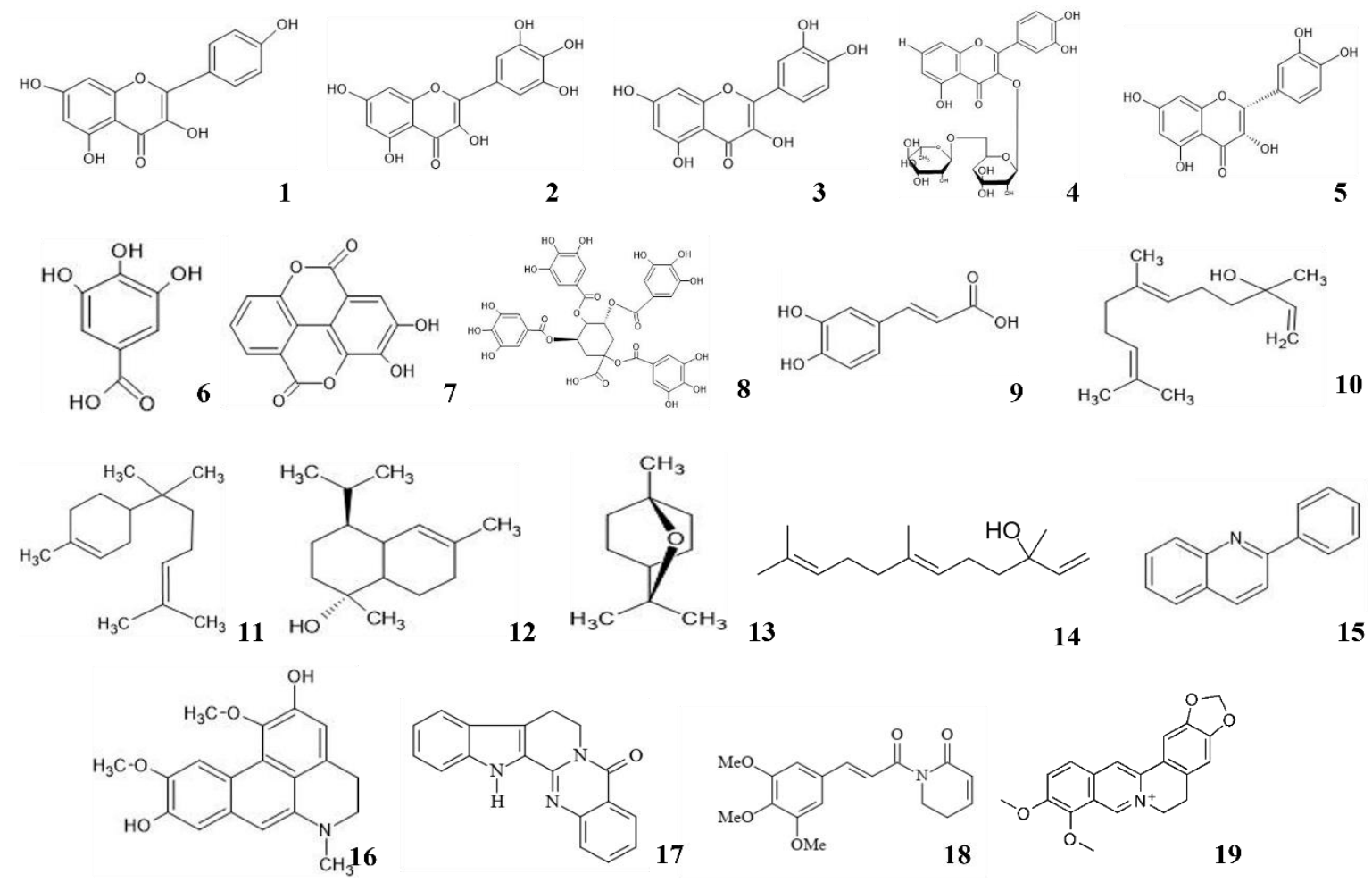

Figure 3. Chemical structure of compounds used with gastroprotection activity. 1 - Kaempferol; 2 - Myricetin; 3 -Quercetin; 4 - Rutin; 5 - Epicatechin; 6 - Gallic acid; 7 - Ellagic acid; 8 - 1,3,4,5-Tetra-O-galloylquinic acid; 9 - Caffeic acid; 10 - Nerolidol; 11 - $\alpha$-bisabolol; 12 - $\alpha$-cadinol; 13 - 1.8 cineole; 14 - Nerolidol; 15 - 2 phenylquinoline; 16 - Boldine; 17 - Rutercapine; 18 - Piplartine, 19 - Berberine.

\subsection{Gastroprotection and natural products.}

\subsubsection{Gastric ulcer.}

The stomach is responsible for storing, mixing food with gastric secretions, and progressively emptying the small intestine. The gastric mucosa consists of mucus-secreting cells and two types of tubular glands, the oxyntic glands, acid-forming, where the hydrogen pump has the main role in the secretion of hydrochloric acid; and the pyloric glands, which in addition to the production of mucus, participates in the control of gastric secretion [42].

Mucus has very important characteristics, with lubricating and protective function of the gastrointestinal tract wall. When the mucosa is not protected, gastric lesions occur, which can progress to ulcers and cancer [25]. Regarding ulcers, this is the term used to indicate the existence of a mucosal lesion, which is caused by an imbalance that occurs between factors that protect the mucosa and factors that attack the mucosa (Figure 4). Therefore, the lesions result from the association between gastric hypersecretion and the physiological imbalance between gastric hormones. Such lesions can lead to loss of local mucosal tissue, promoting the appearance of wounds in deeper areas of the mucosa [43].

Several factors may be related to the development of gastric ulcers, ranging from physiological changes to infections by microorganisms, especially Helicobacter pylori infection and indiscriminate use of nonsteroidal anti-inflammatory drugs. In addition, other factors can cause the emergence of ulcers, such as smoking, use of corticosteroids, excessive use of alcohol, and dietary habits [44]. 


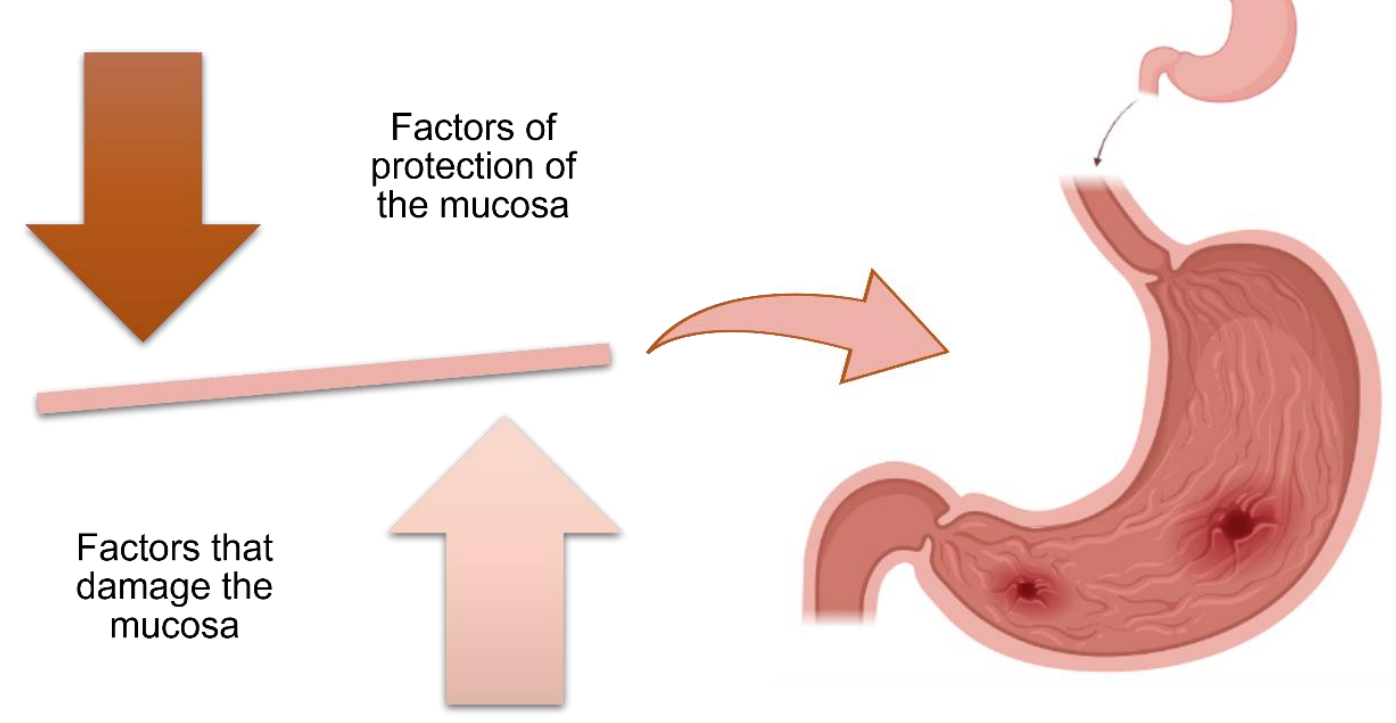

Figure 4. Ulcer cause scheme.

\subsubsection{Treatment.}

The treatment and control of gastric ulcers are primarily aimed at raising the gastric $\mathrm{pH}$ and allowing the gastric mucosa to heal, and such results are achieved with the use of antacid drugs, anticholinergics, $\mathrm{H}_{2}$ histamine receptor antagonists, and proton pump inhibitors. However, the occurrence of side effects is widely observed [45].

Antacids interact with hydrochloric acid because they are weak bases, thus neutralizing gastric acid and reducing the formation of pepsin. This treatment promotes immediate relief of symptoms, but it is temporary and is not considered a definitive therapy. Among the class representatives are aluminum hydroxide, magnesium hydroxide, sodium carbonate, and calcium carbonate $[46,47]$.

$\mathrm{H}_{2}$ receptor antagonists act by reversibly and competitively blocking the binding of histamine to their respective receptors in the membrane (CYP450), thus achieving suppression of gastric acid secretion. Among the main representatives of the class are cimetidine, ranitidine, nizatidine, and famotidine. These drugs act by partially inhibiting acid secretion stimulated by gastrin, and their efficiency occurs mainly at night [46].

Proton pump inhibitors are considered the most effective therapeutic agents in treating ulcers; their main mechanism of action is to irreversibly inhibit the final step of acid secretion through the $\mathrm{H}+\mathrm{K}+$-ATPase pump. Among the main representative drugs of the class are omeprazole, lanzoprazole, pantoprazole, and esomeprazole. The therapeutic efficacy of the class is superior to $\mathrm{H}_{2}$ receptor antagonists and antacids [46].

Despite the diversity of synthetic drugs used in gastroprotection, there are numerous side effects caused by constant use; some of these effects are related to certain classes of drugs and are described in table 1.

Table 1. Treatments (synthetic drugs) used in gastric ulcers and their side effects.

\begin{tabular}{l|l|l}
\multirow{2}{*}{ Treatments } & \multicolumn{1}{|c}{ Side Effect } & Reference \\
\hline \multirow{2}{*}{ Antacids } & Diarrhea & \\
\cline { 2 - 2 } & Constipation & \\
\cline { 2 - 2 } & Hypokalemia & \\
\hline Proton Pump Inhibitors & Acute coronary syndrome & \\
\cline { 2 - 2 } $\begin{array}{l}\text { Associated with antiplatelet } \\
\text { agents) }\end{array}$ & Major cardiovascular events &
\end{tabular}




\begin{tabular}{l|l|c}
\hline \multirow{2}{*}{ Treatments } & \multicolumn{1}{|c}{ Side Effect } & Reference \\
\hline \multirow{4}{*}{ Proton Pump Inhibitors } & Diarrhea, vomit, abdominal pain, intolerance & {$[49]$} \\
\cline { 2 - 3 } & Acquired pneumonia (patients with congenital heart disease) & {$[50]$} \\
\cline { 2 - 3 } & Acute kidney injury & {$[51]$} \\
\hline \multirow{3}{*}{$\begin{array}{l}\text { Histamine receptor antagonists } \\
\left(\mathrm{H}_{2}\right)\end{array}$} & Decrease in sperm & {$[52]$} \\
\cline { 2 - 3 } & Delusions & {$[53]$} \\
\cline { 2 - 3 } & Dermatological reactions & {$[54]$} \\
\cline { 2 - 3 } & Infection and necrotizing enterocolitis in neonates & {$[55]$} \\
\hline
\end{tabular}

\subsubsection{Use of medicinal plants as an alternative.}

In addition to the above-mentioned allopathic medicine, the use of phytotherapeutic drugs to treat this pathology is also worthy of note. In the list of herbal medicines available in the Brazilian market, two medicines are used for the treatment of gastric ulcers: Maytenus ilicifolia (Schrad.), popularly known as "espinheira-santa", which has a well-described gastroprotective activity [56]; and, Cynara scolymus L., known as "alcachofra", which, in addition to gastroprotective activity, has the antioxidant and anti-inflammatory potential [57].

Therefore, one of the alternatives for treatment with fewer side effects, good results, and low cost are the products obtained from medicinal plants [58]. Studies proving the effectiveness of medicinal species in gastroprotection are described by Freitas, Fernandes, Piauilino [59], who reported the gastroprotective effect of the ethanolic extract of Zanthoxylum rhoifolium, increasing mucus and stimulating endogenous prostaglandins, besides presenting an antioxidant mechanism. Studies by de da Silva, Martins, de Oliveira [60] showed that allantoin, isolated from the species M. nodosa, exhibited a gastroprotective role, being associated with reducing the inflammatory process.

The gastroprotective activity can be mediated by several pathways, some of which are related to the involvement of nitric oxide (NO), prostaglandins, described in the research of which, based on a tea produced by infusion of Sedum dendroideum, promoted gastroprotection of ulcers induced by ethanol and indomethacin through the mediation of NO. Opioid receptors, $\alpha 2$-adrenergic receptors, and NO synthesis and stimulation of mucus secretion mediated by prostaglandins were responsible for the gastroprotective effect of the hydroalcoholic extract of Caryocar coriaceum leaves in the study by de Lacerda Neto, Ramos, Santos Sales [61].

Corroborating such evidence, species of the genus Croton have anti-inflammatory and healing properties, besides studies correlating their effect on gastroprotection. The essential oil of Croton rhamnifolioides showed proven gastroprotective effects, decreasing the amount of gastric acid present in the stomach and showing potential antiulcerogenic effect (Vidal, Oliveira Brito Pereira Bezerra Martins, de Alencar Silva [58]. In the study of de Nascimento, Maria-Ferreira, Dal Lin [62], with the species C. cajucara, the extract showed a decrease in ulcers and preservation of gastric mucus due to the secondary metabolites present in the genus of this plant that help in this action.

Júnior et al., obtained a hydroalcoholic extract of $C$. campestres roots and observed the inhibition of lesions in the stomach, helping to protect the tissue [63]. In the studies of Wolff Cordeiro, Aparecida Pinto, Nazari Formagio [64], the gastroprotective activity was also proven using the methanolic extract of $C$. urucurana bark, promoting increased mucus production and decreased gastric acid production.

\subsection{Gênero Croton.}

It is a genus of the Euphorbiaceae family, characteristic of the Brazilian biome, 
especiallythe semiarid climate. It is characterized as a shrub that can reach up to a small tree, adapted to arid conditions [65]. The genus Croton has approximately 1300 species spread in tropical regions, and about 350 species are in Brazil,most of them located in the Northeast. The plants of this genus have chemical compounds that exert biological activities, but many are still unknown [66].

The Croton genus is rich in phenolic compounds and terpenes and is usually found in the leaves, roots, and fruits of the plants, with flavonoids, diterpenes, and alkaloids beingthe most found secondary metabolites $[67,68]$. These metabolites have several properties already described, such as anti-inflammatory, antioxidant, antimicrobial, analgesic, anticancer, diabetes, andhypertension prevention [65, 69].

Several studies are being conducted with plants of the genus of Croton. da Silva Brito, Silva, Malheiro [66] conducted a study characterizing an essential oil of Croton argyrophyllus, in which it observed antioxidant and antimicrobial action, inhibiting thegrowth of gram-positive and gram-negative bacteria. An ethanolic fraction of Alcalypha indica and Croton bonplandianus [70] showed dualantibacterial and anticancer activity by decreasing the growth of multidrug-resistant gram-negative bacteria and blood cancer cells. According to the work of [68], Croton velutinus species has phenylpropanoid derivatives, which were ableto inhibit the growth of cancer cell lines, trypanocidal and anti-inflammatory activity.

\subsubsection{Croton blanchetianus.}

Croton blanchetianus is a species found in the Caatinga, popularly known as the quince tree.It has simple leaves containing phenolic compounds that help heal disorders in the body [5]. It is a species widely used by the population because it is reported to have medicinal properties, being used in the preparation of teas, compresses, baths, helping in inflammatory processes and pain [7].

Studies of Pereira et al. (2020) correlated the composition of the ethanolic extract of $C$. blanchetianus with potential leishmanicidal action, presenting activity against promastigotes and amastigotes forms of L. amazonenses and L. infantum. Anotherresearch with the species [6], showed antibiofilm actionagainst strains of $S$. mutans and S. parasaguinis from diterpenes present in the plant root, exerting therapeutic potential in oral streptococcal infections. Moreover, its action in inflammatory processes is also described in the literature, as in [7], who studied the ethanolic extract of $C$. blanchetianus leaves and observed a decrease in pain and inflammation in mice, presenting analgesic activity. Recently, studies [71] demonstrated the absence of toxicity of a polyphenol-richfraction obtained from the species leaves' ethanolic extract and increased antioxidant activity.

Considering the above, the studies with the species Croton blanchetianus have demonstrated good results against inflammation and antimicrobial action. However, studies on gastroprotection are not described for this species, even though the activity is proven for some species of the genus, thus contributing to good results with $C$. blanchetianus.

\section{Conclusions}

Plants have a variety of pharmacological activities, being used in several ways to treat diseases. The secondary metabolites in plants play a fundamental role in these activities, providing greater knowledge about these natural products. Among the therapeutic potentials, the gastroprotective activity is being widely studied, where the compounds present in the plants 
improve the production of gastric mucus and tissue healing. Thus, we have seen that the plants of the genus Croton have great potentialin anti-inflammatory activity and gastroprotection. Therefore, studies with the species Croton blanchetianus should be deepened regarding this activity, providing greater knowledge about this plant.

\section{Funding}

This research was funded by Coordenação de Aperfeiçoamento de Pessoal de Nível Superior (88887.533173/2020-00).

\section{Acknowledgments}

This work was supported by Conselho Nacional de Desenvolvimento Científico e Tecnológico (CNPq -405297/2018-1 and 307110/2018-4) and Fundação de Amparo à Ciência e Tecnologia do Estado de Pernambuco (APQ-0493-4.03/14) in the form of funding from Luiz Alberto Lira Soares.

\section{Conflicts of Interest}

The authors declare no conflict of interest.

\section{References}

1. Barone, R.P.; Knittel, D.K.; Ooka, J.K.; Porter, L.N., et al. The production of plant natural products beneficial to humanity by metabolic engineering. Curr. Plant Biol., 2020. 24, 100121, https://doi.org/10.1016/j.cpb.2019.100121.

2. Taïbi, K.; Abderrahim, L.A.; Ferhat, K.; Betta, S., et al. Ethnopharmacological study of natural products used for traditional cancer therapy in Algeria. Saudi Pharmaceutical Journal, 2020. 28, 11, 1451-1465, https://doi.org/10.1016/j.jsps.2020.09.011.

3. Muhammad, A.; Feng, X.; Rasool, A.; Sun, W.; et al. production of plant natural products through engineered Yarrowia lipolytica. Biotechnol. Adv. 2020. 43, 107555, https://doi.org/10.1016/j.biotechadv.2020.107555.

4. Gori, A.; Boucherle, B.; Rey, A.; Rome, M., et al. development of an innovative maceration technique to optimize extraction and phase partition of natural products. Fitoterapia, 2021. 148, 104798, https://doi.org/10.1016/j.fitote.2020.104798.

5. Mendes, K.R.; Granja, J.A.A.; Ometto, J.P.; Antonino, A.C.D.; et al. Croton blanchetianus modulates its morphophysiological responses to tolerate drought in a tropical dry forest. Funct. Plant Biol. 2017, 44, 10, 1039-1051, https://doi.org/10.1071/FP17098.

6. Sá Firmino, N.C.; Alexandre, F.S.O.; de Vasconcelos, M.A.; Pinheiro, A.A., et al., Diterpenes isolated from Croton blanchetianus Baill: Potential compounds in prevention and control of the oral Streptococci biofilms. Ind. Crop Prod., 2019. 131, 371-377, https://doi.org/10.1016/j.indcrop.2019.01.062.

7. Freitas, A.F.S.; Costa, W.K.; Machado, J.C.B.; Ferreira, M.R.A., et al., Toxicity assessment and antinociceptive activity of an ethanolic extract from Croton blanchetianus (Euphorbiaceae) leaves. S. Afr. J. Bot., 2020. 133, 30-39, https://doi.org/10.1016/j.sajb.2020.06.015.

8. Birchfield, A.S.; McIntosh, C.A. Metabolic engineering and synthetic biology of plant natural products $-\mathrm{A}$ minireview. Curr. Plant Biol., 2020. 24, 100163, https://doi.org/10.1016/j.cpb.2020.100163.

9. Guerriero, G.; Berni, R.; Muñoz-Sanchez, J.A.; Apone, F., et al. Production of Plant Secondary Metabolites: Examples, Tips and Suggestions for Biotechnologists. Genes (Basel), 2018. 9, 6, 309, https://doi.org/10.3390/genes9060309.

10. Romanowski, S.; Eustáquio, A.S., Synthetic biology for natural product drug production and engineering. Curr. Opin. Chem. Biol., 2020. 58, 137-145, https://doi.org/10.1016/j.cbpa.2020.09.006.

11. Ikonne, E.U.; Ikpeazu, V.O.; Ugbogu, E.A. The potential health benefits of dietary natural plant products in age related eye diseases. Heliyon, 2020. 6, 7, e04408, https://doi.org/10.1016/j.heliyon.2020.e04408.

12. Nazar, S.; Hussain, M.A.; Khan, A.; Muhammad, G., et al. Alkaloid-rich plant Tylophora indica; current trends in isolation strategies, chemical profiling and medicinal applications. Arab. J. Chem., 2020. 13, 8, 6348-6365, https://doi.org/10.1016/j.arabjc.2020.05.037.

13. Liu, R.; Yu, D.; Deng, Z.; Liu, T., Harnessing in vitro platforms for natural product research: in vitro driven rational engineering and mining (iDREAM). Curr. Opin. Biotechnol., 2021. 69, 1-9, https://doi.org/10.1016/j.copbio.2020.08.006. 
14. Evans, W.; Trease and Evans, Pharmacognosy. 2010: Saunders Ltd. 600.

15. Jain, P. Secondary metabolites for antiulcer activity. Nat. Prod. Res., 2016. 30, 6, 640-656, https://doi.org/10.1080/14786419.2015.1036269.

16. Neri-Numa, I.A.; Arruda, H.S.; Geraldi, M.V.; Maróstica Júnior, M.R., et al., Natural prebiotic carbohydrates, carotenoids and flavonoids as ingredients in food systems. Curr. Opin. Food Sci. 2020, 33, 98-107, https://doi.org/10.1016/j.cofs.2020.03.004.

17. Owona, B.A.; Abia, W.A.; Moundipa, P.F. Natural compounds flavonoids as modulators of inflammasomes in chronic diseases. International Immunopharmacology, 2020. 84, 106498, https://doi.org/10.1016/j.intimp.2020.106498.

18. Chen, R.; Huang, L.; Hu, K. Natural products remodel cancer-associated fibroblasts in desmoplastic tumors. Acta Pharmaceutica Sinica B, 2020. 10, 11, 2140-2155, https://doi.org/10.1016/j.apsb.2020.04.005.

19. Spinaci, M.; Bucci, D.; Muccilli, V.; Cardullo, N.; et al. A polyphenol-rich extract from an oenological oakderived tannin influences in vitro maturation of porcine oocytes. Theriogenology, 2019. 129, 82-89, https://doi.org/10.1016/j.theriogenology.2019.02.017.

20. Del Bianco, S.; Natalello, A.; Luciano, G.; Valenti, B.; et al. Influence of dietary inclusion of tannin extracts from mimosa, chestnut and tara on volatile compounds and flavour in lamb meat. Meat Science 2021, 172, 108336, https://doi.org/10.1016/j.meatsci.2020.108336.

21. Ardalani, H.; Hadipanah, A.; Sahebkar, A. Medicinal Plants in the Treatment of Peptic Ulcer Disease: A Review. Mini Rev. Med. Chem., 2020. $20, \quad 8, \quad$ 662-702, https://doi.org/10.2174/1389557520666191227151939.

22. Kim, J.; Gripenberg, S.; Karonen, M.; Salminen, J.-P. Seed tannin composition of tropical plants. Phytochemistry 2021, 187, 112750, https://doi.org/10.1016/j.phytochem.2021.112750.

23. Rajasekaran, S.; Rajasekar, N.; Sivanantham, A. Therapeutic potential of plant-derived tannins in nonmalignant respiratory diseases. The Journal of Nutritional Biochemistry 2021, 108632, https://doi.org/10.1016/j.jnutbio.2021.108632.

24. Andreo, M.A.; Ballesteros, K.V.R.; Hiruma-Lima, C.A.; Machado da Rocha, L.R.; et al. Effect of Mouriri pusa extracts on experimentally induced gastric lesions in rodents: Role of endogenous sulfhydryls compounds and nitric oxide in gastroprotection. J. Ethnopharmacol., 2006. 107, 3, 431-441, https://doi.org/10.1016/j.jep.2006.04.001.

25. de Cássia dos Santos, R.; Bonamin, F.; Périco, L.L.; Rodrigues, V.P.; et al. Byrsonima intermedia A. Juss partitions promote gastroprotection against peptic ulcers and improve healing through antioxidant and antiinflammatory activities. Biomed. Pharmacother. 2019. 111, 1112-1123, https://doi.org/10.1016/j.biopha.2018.12.132.

26. Benvenutti, R.C.; Dalla Vecchia, C.A.; Locateli, G.; Serpa, P.Z.; et al. Gastroprotective activity of hydroalcoholic extract of the leaves of Urera baccifera in rodents. J. Ethnopharmacol. 2020, 250, 112473, https://doi.org/10.1016/j.jep.2019.112473.

27. Wang, X.-j.; Li, Y.-k.; Song, H.-c.; Tao, Y.-s.; et al. Phenolic matrix effect on aroma formation of terpenes during simulated wine fermentation - Part I: Phenolic acids. Food Chemistry 2021, 341, 128288, https://doi.org/10.1016/j.foodchem.2020.128288.

28. Kopaczyk, J.M.; Warguła, J.; Jelonek, T. The variability of terpenes in conifers under developmental and environmental stimuli. Environmental and Experimental Botany 2020, 180, 104197, https://doi.org/10.1016/j.envexpbot.2020.104197.

29. Nawade, B.; Shaltiel-Harpaz, L.; Yahyaa, M.; Kabaha, A.; et al. Characterization of terpene synthase genes potentially involved in black fig fly (Silba adipata) interactions with Ficus carica. Plant Science 2020, 298, 110549, https://doi.org/10.1016/j.plantsci.2020.110549.

30. Silva, E.; Oliveira, F.; Silva, J.M.; Reis, R.L.; et al. Untangling the bioactive properties of therapeutic deep eutectic solvents based on natural terpenes. Curr. Research in Chemical Biology 2021, 100003, https://doi.org/10.1016/j.crchbi.2021.100003.

31. Lasram, S.; Zemni, H.; Hamdi, Z.; Chenenaoui, S.; et al. Antifungal and antiaflatoxinogenic activities of Carum carvi L., Coriandrum sativum L. seed essential oils and their major terpene component against Aspergillus flavus. Ind. Crop Prod. 2019, 134, 11-18, https://doi.org/10.1016/j.indcrop.2019.03.037.

32. Achika, J.I.; Ayo, R.G.; Habila, J.D.; Oyewale, A.O. Terpenes with antimicrobial and antioxidant activities from Lannea humilis (Oliv.). Scientific African 2020, 10, e00552, https://doi.org/10.1016/j.sciaf.2020.e00552.

33. de O. Leite, G.; da Penha, A.R.; Fernandes, C.N.; Souza, H.H.F.; et al. Gastroprotective mechanism of Vanillosmopsis arborea bark essential oil. Fitoterapia 2009, 80, 77-80, https://doi.org/10.1016/j.fitote.2008.10.008.

34. de Souza, E.P.B.S.S.; Gomes, M.V.L.D.; dos Santos Lima, B.; Silva, L.A.S.; et al. Nerolidol-betacyclodextrin inclusion complex enhances anti-inflammatory activity in arthritis model and improves gastric protection. Life Sci. 2021. 265, 118742, https://doi.org/10.1016/j.lfs.2020.118742.

35. Do Nascimento, R.F.; De Sales, I.R.P.; De Oliveira Formiga, R.; Barbosa-Filho, J.M. et al. Activity of Alkaloids on Peptic Ulcer: What's New?. Molecules 2015, 20, 929-950, https://doi.org/10.3390/molecules20010929. 
36. Bai, R.; Yao, C.; Zhong, Z.; Ge, J.; et al. Discovery of natural anti-inflammatory alkaloids: Potential leads for the drug discovery for the treatment of inflammation. European Journal of Medicinal Chemistry 2021. 213, 113165, https://doi.org/10.1016/j.ejmech.2021.113165.

37. Li, L.S.; Chiroma, S.M.; Hashim, T.; Adam, S.K.; et al. Antioxidant and anti-inflammatory properties of Erythroxylum cuneatum alkaloid leaf extract. Heliyon 2020. 6, e04141, https://doi.org/10.1016/j.heliyon.2020.e04141.

38. Saddiqe, Z.; Wahab, U.; Maimoona, A.; Raheel, R., et al., Alkaloid rich fraction of Datura alba Rumph. ex Nees leaves possesses antitumor and antimitotic activity. South African Journal of Botany 2018. 117, 282287, https://doi.org/10.1016/j.sajb.2018.05.031.

39. Zhang, Y.; Bai, X.; Yuwen, H.-S.; Guo, L.-L.; et al. Alkaloids from Tabernaemontana divaricata combined with fluconazole to overcome fluconazole resistance in Candida albicans. Bioorganic Chemistry 2021. 107, 104515, https://doi.org/10.1016/j.bioorg.2020.104515.

40. Ugwah, M.O.; Ugwah-Oguejiofor, C.J.; Etuk, E.U.; Bello, S.O.; et al. evaluation of the antiulcer activity of the aqueous stem bark extract of Balanites aegyptiaca L Delile in Wistar rats. J. Ethnopharmacol. 2019, 239, 111931, https://doi.org/10.1016/j.jep.2019.111931.

41. Breviglieri, E.; Mota da Silva, L.; Boeing, T.; Somensi, L.B.; et al. Gastroprotective and anti-secretory mechanisms of 2-phenylquinoline, an alkaloid isolated from Galipea longiflora. Phytomedicine 2017, 25, 6170, https://doi.org/10.1016/j.phymed.2016.12.016.

42. HALL, J.E. Tratado de Fisiologia Médica. 2011, Rio de Janeiro: Elsevier.

43. Lanas, A.; Chan, F.K.L. Peptic ulcer disease. Lancet 2017. 390, 613-624, https://doi.org/10.1016/s01406736(16)32404-7.

44. Alexander, S.M.; Retnakumar, R.J.; Chouhan, D.; Devi, T.N.B.; et al. Helicobacter pylori in Human Stomach: The Inconsistencies in Clinical Outcomes and the Probable Causes. Frontiers in Microbiolgy 2021, 12, 2277, https://doi.org/10.3389/fmicb.2021.713955.

45. Das, A.K.; Bigoniya, P.; Verma, N.K.; Rana, A.C. Gastroprotective effect of Achyranthes aspera Linn. leaf on rats. Asian Pac. J. Trop. Med. 2012. 5, 197-201, https://doi.org/10.1016/S1995-7645(12)60024-8.

46. Fox, R.K.; Muniraj, T. Pharmacologic Therapies in Gastrointestinal Diseases. Med. Clin. North Am., 2016. 100, 827-50, https://doi.org/10.1016/j.mcna.2016.03.009.

47. Singh, A.K.; Singh, S.K.; Singh, P.P.; Srivastava, A.K.; et al. Biotechnological aspects of plants metabolites in the treatment of ulcer: A new prospective. Biotechnol. Rep. 2018, 18, e00256, https://doi.org/10.1016/j.btre.2018.e00256.

48. Huang, B.; Huang, Y.; Li, Y.; Yao, H.; et al. Adverse cardiovascular effects of concomitant use of proton pump inhibitors and clopidogrel in patients with coronary artery disease: a systematic review and metaanalysis. Arch. Med. Res. 2012. 43, 212-224, https://doi.org/10.1016/j.arcmed.2012.04.004.

49. Davies, M.; Wilton, L.V.; Shakir, S.A. Safety profile of esomeprazole: results of a prescription-event monitoring study of 11595 patients in England. Drug Saf. 2008, 31, 313-23, https://doi.org/10.2165/00002018-200831040-00005.

50. Evers, P.D.; Farkas, D.K.; Khoury, M.; Olsen, M.; et al. Proton-pump inhibitor use and risk of communityacquired pneumonia in congenital heart disease patients. Int. J. Cardiology Congenital Heart Disease 2021, 4, 100152, https://doi.org/10.1016/j.ijcchd.2021.100152.

51. Klepser, D.G.; Collier, D.S.; Cochran, G.L. Proton pump inhibitors and acute kidney injury: a nested casecontrol study. BMC Nephrol. 2013, 14, 150, https://doi.org/10.1186/1471-2369-14-150.

52. Banihani, S.A. Histamine-2 Receptor Antagonists and Semen Quality. Basic Clin. Pharmacol. Toxicol. 2016, 118, 1, 9-13, https://doi.org/10.1111/bcpt.12446.

53. Kikkawa, N.; Sogawa, R.; Monji, A.; Sumi, S.; et al. Delirium risk of histamine-2 receptor antagonists and proton pump inhibitors: A study based on the adverse drug event reporting database in Japan. General Hospital Psychiatry 2021, 72, 88-91, https://doi.org/10.1016/j.genhosppsych.2021.07.010.

54. MacLaren, R.; Reynolds, P.M.; Allen, R.R. Histamine-2 receptor antagonists vs proton pump inhibitors on gastrointestinal tract hemorrhage and infectious complications in the intensive care unit. JAMA Intern. Med. 2014, 174, 564-74, https://doi.org/10.1001/jamainternmed.2013.14673.

55. Dos Santos, C.A.-O.X.; Mizobucchi, A.L.; Escaramboni, B.; Lopes, B.P.; et al. Optimization of Eugenia punicifolia (Kunth) D. C. leaf extraction using a simplex centroid design focused on extracting phenolics with antioxidant and antiproliferative activities. BMC Chem. 2019. 14, https://doi.org/10.1186/s13065-02000686-2.

56. Tabach, R.; Duarte-Almeida, J.M.; Carlini, E.A. Pharmacological and Toxicological Study of Maytenus ilicifolia Leaf Extract. Part I - Preclinical Studies. Phytother. Res. 2017. 31, 915-920, https://doi.org/10.1002/ptr.5818.

57. Ben Salem, M.; Affes, H.; Athmouni, K.; Ksouda, K.; et al. Chemicals Compositions, Antioxidant and AntiInflammatory Activity of Cynara scolymus Leaves Extracts, and Analysis of Major Bioactive Polyphenols by HPLC. Evid. Based Complement. Alternat. Med. 2017, 2017, 4951937, https://doi.org/10.1155/2017/4951937. 
58. Vidal, C.S.; Oliveira Brito Pereira Bezerra Martins, A.; de Alencar Silva, A.; de Oliveira, M.R.C.; et al. Gastroprotective effect and mechanism of action of Croton rhamnifolioides essential oil in mice. Biomed. Pharmacother. 2017, 89, 47-55, https://doi.org/10.1016/j.biopha.2017.02.005.

59. Freitas, F.F.B.P.; Fernandes, H.B.; Piauilino, C.A.; Pereira, S.S.; et al. Gastroprotective activity of Zanthoxylum rhoifolium Lam. in animal models. J. Ethnopharmacol. 2011, 137, 700-708, https://doi.org/10.1016/j.jep.2011.06.026.

60. da Silva, D.M.; Martins, J.L.R.; de Oliveira, D.R.; Florentino, I.F.; et al. Effect of allantoin on experimentally induced gastric ulcers: Pathways of gastroprotection. Eur. J. Pharmacol. 2018, 821, 68-78, https://doi.org/10.1016/j.ejphar.2017.12.052.

61. de Lacerda Neto, L.J.; Ramos, A.G.B.; Santos Sales, V.; de Souza, S.D.G.; et al. Gastroprotective and ulcer healing effects of hydroethanolic extract of leaves of Caryocar coriaceum: Mechanisms involved in the gastroprotective activity. Chem.-Biol. Interact. 2017, 261, 56-62, https://doi.org/10.1016/j.cbi.2016.11.020.

62. Nascimento, A.M.; Maria-Ferreira, D.; Dal Lin, F.T.; Kimura, A.; et al. Phytochemical analysis and antiinflammatory evaluation of compounds from an aqueous extract of Croton cajucara Benth. J. Pharm. Biomed. Anal. 2017, 145, 821-830, https://doi.org/10.1016/j.jpba.2017.07.032.

63. Júnior, F.E.B.; de Oliveira, D.R.; Boligon, A.A.; Athayde, M.L. et al. Protective effects of Croton campestris A. St-Hill in different ulcer models in rodents: Evidence for the involvement of nitric oxide and prostaglandins. J. Ethnopharmacol. 2014, 153, 2, 469-477, https://doi.org/10.1016/j.jep.2014.03.005.

64. Wolff Cordeiro, K.; Aparecida Pinto, L.; Nazari Formagio, A.S.; Faloni de Andrade, S.; et al. Antiulcerogenic effect of Croton urucurana Baillon bark. J. Ethnopharmacol. 2012, 143, 331-337, https://doi.org/10.1016/j.jep.2012.06.044.

65. Pimentel, B.S.; Negri, G.; Cordeiro, I.; Motta, L.B.; et al. Taxonomic significance of the distribution of constituents of leaf cuticular waxes of Croton species (Euphorbiaceae). Biochem. Syst. Ecol. 2020, 92, 104106, https://doi.org/10.1016/j.bse.2020.104106.

66. da Silva Brito, S.S.; Silva, F.; Malheiro, R.; Baptista, P.; et al. Croton argyrophyllus Kunth and Croton heliotropiifolius Kunth: Phytochemical characterization and bioactive properties. Ind. Crop Prod. 2018, 113, 308-315, https://doi.org/10.1016/j.indcrop.2018.01.044.

67. Queiroz, S.A.S.; Pinto, M.E.F.; Bobey, A.F.; Russo, H.M.; et al. Diterpenoids with inhibitory activity of nitrite production from Croton floribundus. J. Ethnopharmacol. 2020, 249, 112320, https://doi.org/10.1016/j.jep.2019.112320.

68. Abreu, L.S.; do Nascimento, Y.M.; do Espirito-Santo, R.F.; Meira, C.S.; et al. Phenylpropanoids from Croton velutinus with cytotoxic, trypanocidal and anti-inflammatory activities. Fitoterapia 2020, 145, 104632, https://doi.org/10.1016/j.fitote.2020.104632.

69. Pereira, K.L.G.; Vasconcelos, N.B.R.; Braz, J.V.C.; InÁcio, J.D.F.; et al. Ethanolic extract of Croton blanchetianus Ball induces mitochondrial defects in Leishmania amazonensis promastigotes. An. Acad. Bras. Cienc. 2020, 92, e20180968, https://doi.org/10.1590/0001-3765202020180968.

70. Suresh, M.; Alfonisan, M.; Alturaiki, W.; Al Aboody, M.S.; et al. Investigations of Bioactivity of Acalypha indica (L.), Centella asiatica (L.) and Croton bonplandianus (Baill) against Multidrug Resistant Bacteria and Cancer Cells. J. Herb. Med. 2021, 28, 100359, https://doi.org/10.1016/j.hermed.2020.100359.

71. de Oliveira, A.M.; de Freitas, A.F.S.; Costa, W.K.; Machado, J.C.B.; et al. Flavonoid-rich fraction of Croton blanchetianus Baill. (Euphorbiaceae) leaves: Chemical profile, acute and subacute toxicities, genotoxicity and antioxidant potential. S. Afr. J. Bot. 2022, 144, 238-249, https://doi.org/10.1016/j.sajb.2021.08.040. 